\title{
Semantikas noteikta sakārtotu komponentu secība latviešu valodā
}

\section{Semantics and the order of coordinated components in Latvian}

\author{
Guna Zvīgule \\ Latviešu un vispārīgās valodniecības katedra \\ Latvistikas un baltistikas nodal̨a \\ Humanitāro zinātṇu fakultāte, Latvijas Universitāte \\ Visvalža iela 4a, Rīga LV-1050, Latvija \\ E-pasts: guna.zvigule@gmail.com
}

\begin{abstract}
Rakstā aplūkota sakārtojumā saistītu komponentu secība latviešu valodā. Balstoties līdzšinējos latviešu un cittautu valodnieku pētījumos un secinājumos, izvirzīti vairāki faktori, kas ietekmē vārdu secību sakārtojuma konstrukcijā. Valoda rāda, ka sakārtojumā saistìtu komponentu secība, lai arī gramatiski nenoteikta, nav patvaḷịga. To ietekmē trīs faktoru grupas: 1) semantiskie faktori, 2) funkcionāli pragmatiskie faktori, 3) formālie faktori.

Raksta uzmanības centrā ir semantiskie faktori, kas latviešu valodā noteic sakārtojumā saistìtu komponentu pamatsecību. Tā kā saistīto komponentu semantika ir ḷoti daudzveidīga, semantiskie faktori dalīti vairākās grupās atkarībā no saistīto komponentu nozīmes. Kā atsevišķi aspekti analizēti: 1) realitātes noteikts secīgums, 2) hierarhiskās attieksmes, 3) kognitīvi emocionālie aspekti. To ietekme pētīta valodas materiālā, kas izgūts no „Līdzsvarotā mūsdienu latviešu valodas tekstu korpusa” un uz tā pamata veidotā „Latviešu valodas sintaktiski marḳetā korpusa" un ir semantiski un formāli daudzveidīgs, jo skatītas vārdrindas, kur saistīti ar lietvārdiem, darbības vārdiem, apstākḷa vārdiem un īpašības vārdiem izteikti vienkārša teikuma komponenti.
\end{abstract}

Atslēgvārdi: sakārtojuma sakars; vārdrinda; vārdu secība; semantika; semantiskie faktori.

\section{levads}

Latviešu sintaksē sakārtojuma sakars uzskatīts par vienkāršāko sintaktisko sakaru (Lokmane 2013, 88), ko realizē, teikumā noteiktā pozīcijā iesaistot kvalitatīvi ekvivalentus komponentus, kas teikuma hierarhisko struktūru informatīvi paplašina, nevis maina (Freimane 1985, 92). Sakārtojuma konstrukcijas izveidi noteic vairāki ierobežojumi: pirmkārt, saistītajiem komponentiem jābūt sintaktiski un funkcionāli līdzvērtīgiem un, otrkārt, to saistījumam - pragmatiski motivētam (Lohmann 2013, 4-6). Neievērojot minētās valodas normas, vārdrindu jeb sakārtojumā saistītu vārdu savienojumu (Skujiņa 2007, 436) formāli iespējams izveidot, taču tā būs ārkārtēji neparasta un negramatiska, jo saistītie komponenti nevar būt un vienlaikus nebūt līdzvērtīgi (Schachter 1977, 102). Valodā visdrīzāk nesastapsim tādus teikumus kā Māsa devās cel̦ojumā kopāa ar māti un kājām, kur sakārtojumā saistītajiem komponentiem ir dažādas semantiskās lomas. 
Latviešu valodā kā fleksīvā valodā sintaktiskos sakarus visbiežāk izsaka ar vārdu gramatiskajām formām, tas nozīmē, ka vārdu secība teikumā ir relatīvi brīva (Lokmane 2010, 59, 61), tāpēc būtiska vārdrindas pazīme ir nedalāmība - saistītie komponenti veido vienotu veselumu, kas ir līdzvērtīgs katram atsevišķajam komponentam (Quirk et al. 1985, 945), un, mainot tā novietojumu teikumā, tas nav dalāms. Piem., vārdu secību teikumā Tur ir mamma un tētis ir iespējams pārveidot un propozīciju jeb teikuma semantisko modeli (Skujiņa 2007, 314) izteikt citādi Têtis un mamma ir tur. Pievēršot uzmanību vārdrindai, redzams, ka tā netiek dalīta, taču komponentu secību var mainīt, turklāt izmaiņas neietekmē nedz to nozīmi, nedz teikuma informācijas struktūru. Tas nozīmē, ka sakārtojumā saistītu komponentu secība nav gramatiski noteikta, tomēr par patvalīigu to dēvēt nevar. Pirmkārt, dzimtās valodas runātājs intuitīvi, pat neapzināti ne tikai fiksē izmaiņas komponentu secībā un tās neatbilsmi ierastajai, bet arī citādi uztver teikto vai lasīto. Otrkārt, aplūkojot plašāku valodas materiālu, vērojamas noteiktas sakārtotu komponentu secības tendences. Tātad log̣isks ir jautājums - kas noteic komponentu secību vārdrindā?

Latviešu valodniecībā sakārtotu komponentu secības īpatnības pētītas maz. Ievērojamākie darbi, kur uzmanība pievērsta arī vārdu secībai vārdrindā, ir Tamāras Porītes doktora disertācija (1954) un Artura Ozola (1993) pētījums par latviešu tautasdziesmu valodu. T. Porīte $(1954,241)$, skatot vārdu secības īpatnības vārdkopā, kur apzīmējamajam vārdam piesaistīti vairāki apzīmētāji, ievērojusi noteiktas likumības apzīmētāju secībā un izvirzījusi vairākus faktorus, kas to ietekmē, - apzīmētāja vārdšķira, apzīmētāju savstarpējās attieksmes un attieksmes pret apzīmējamo vārdu, konteksts, loǵiskais uzsvars un teikuma ritms, ko ietekmē vārda garums. Būtisku sakārtotu komponentu secības īpatnību novērojis A. Ozols (1993, 234) un, analizējot vārdrindu lietojumu latviešu tautasdziesmās, norāda, ka verbu lineārā secība vārdrindā ir cieši saistīta ar nosaukto procesu vai stāvokḷu secīgumu realitātē.

Ārpus Latvijas robežām šī jautājuma izpētei pievērsušies vairāki pētnieki. Viens no pirmajiem, arī plašāk zināmajiem pētījumiem ir Jakova Malkīla (Yakov Malkiel 1959) „Studies in irreversible binominals” („Pētîjums par neapvēršamiem binomināliem savienojumiem"). Rakstā J. Malkīls analizē vārdu secības īpatnības sakārtojuma konstrukcijās angḷu, vācu, franču, spāṇu, krievu, arī grieķu un poḷu valodā, konstatē gan kopīgas, gan atšķirīgas iezīmes komponentu secībā un izvirza vairākus faktorus, kas noteic sakārtojumā saistīto komponentu secību. J. Malkīla vērojumi un secinājumi plaši izmantoti vēlākos pētījumos, kas ir daudzveidīgi gan pētītā valodas materiāla, gan izmantoto metožu ziņā. Jaunākie pētījumi (piem., Sāras Benoras, Rodžera Levi (Sarah Bunin Benor, Roger Levy 2006) pētījums un Arnes Lomaṇa (Arne Lohmann 2013) doktora disertācija) ir balstīti kognitīvās lingvistikas atzin̄ās, un to pamatā ir valodas korpusa datu analīze. Minētajos teorētiskajos un praktiskajos pētîjumos iegūtie rezultāti un secinājumi pēc būtības ir vienādi - sakārtojumā saistītu komponentu secību ietekmē to semantika, konsituācija, kādā tie lietoti, un formālā uzbūve (sk. arī Cooper, Ross 1975; Allan 1987). Nozīmīgākās atšķirības vērojamas faktoru definējumā un klasifikācijā.

Salīdzinot minēto pētnieku secinājumus par sakārtojumā saistītu komponentu secību, ir pamats uzskatīt, ka šīs idejas iespējams izmantot arī latviešu valodas 
faktu analīzē. Pirmkārt, latviešu valodā ir novērota un pētīta atsevišķu semantisko, pragmatisko, arī formālo faktoru ietekme uz sakārtojumā saistītu komponentu secību (sk. Porīte 1954; Ozols 1993). Otrkārt, izvirzītie faktori saistāmi ar cilvēka pasaules uztveres un izziņas īpatnībām un ir semantiski vispārināti. Apkopojot šo pētījumu rezultātus un tajos gūtās atziṇas, taču galvenokārt balstoties uz A. Lomaņa (2013) un S. Benoras un R. Levi (2006) veidoto klasifikāciju, šķirti vairāki faktori, kas dalāmi trīs grupās atkarībā no tā, ar kādu valodas līmeni to ietekme saistāma. Tie ir:

1) semantiskie faktori;

2) funkcionāli pragmatiskie faktori;

3) formālie faktori.

Semantisko faktoru ietekme uz sakārtojumā saistītu komponentu secību vērojama neatkarīgi no konsituācijas, kādā vārdrinda lietota, savukārt funkcionāli pragmatiskie faktori - informācijas statuss un uzsvars un referenta statuss un sasaiste - ir cieši saistīti ar valodas komunikatīvo funkciju. To noteiktā komponentu secība ir atkarīga no konsituācijas, kādā vārdrinda lietota, un saziṇas dalībnieku komunikatīvā mērķa. Šī iemesla dēḷ funkcionāli pragmatisko faktoru ietekmē var tikt pārkāpta citu faktoru noteiktā secība (Zvīgule 2019, 86-87). Savukārt, izvirzot formālus faktorus, kas paredz, ka formāli sarežǵītāks komponents seko vienkāršākam, vērā ņemta saistīto komponentu formālā - fonologiskā, morfoloǵiskā, sintaktiskā - uzbūve, arī prosodija un ritmiskums (sk., piem., Cooper, Ross 1975; Benor, Levy 2006; Lohmann 2013). Līdzās semantiskajiem un funkcionāli pragmatiskajiem faktoriem formālie faktori ir sekundāri un tiek bieži pārkāpti. To ietekme ir izšķiroša vien tad, ja komponentu semantiskās un funkcionālās pazīmes ir ekvivalentas vai arī šo faktoru ietekme nav vērojama (Cooper, Ross 1975, 71; Zvīgule 2019, 84-85).

Analizējot vārdu secību un tās īpatnības, kā arī mēǵinot noteikt faktorus, kas ietekmē sakārtojumā saistīto komponentu secību, izejas punkts ir vārdu pamatsecība - tieša jeb neitrāla vārdu secība, kas izsaka pamatinformāciju bez emocionālas vai stilistiskas papildinformācijas, nebalstās uz kontekstu un ko nenosaka kāds īpašs komunikatīvs nolūks vai uzsvars (Skujiņa 2007, 403). Sakārtojumā saistītu komponentu pamatsecību nosaka semantiskie faktori, tāpēc šajā rakstā galvenā uzmanība veltīta semantisko faktoru ietekmes analīzei latviešu valodā. Tas tapis uz G. Zvīgules maǵistra darba „Sakārtojumā saistītu komponentu secība latviešu valodā” (2019) pamata.

Valodas piemēru avoti ir „Līdzsvarotais mūsdienu latviešu valodas tekstu korpuss” un uz tā pamata veidotais „Latviešu valodas sintaktiski marķētais korpuss". Tie ir līdzsvaroti un vispārīgi tekstu korpusi, kas latviešu valodu atspoguḷo iespējami daudzveidīgi, ietverot visus valodas funkcionālos stilus un visplašāko tematiku. Valodas materiāla atlasei noteikti divi ierobežojumi:

1) sakārtojumā saistīti vienkārša teikuma komponenti;

2) saistītie komponenti izteikti ar lietvārdiem, darbības vārdiem, apstākḷa vārdiem vai īpašības vārdiem.

Citi ierobežojumi netika izvirzīti, tādēl analizētais valodas materiāls ir semantiski un formāli daudzveidīgs. 


\section{Semantiskie faktori}

Valoda ir zīmju sistēma kā cilvēka sazināšanās un domu formulēšanas un izteikšanas līdzeklis informācijas fiksēšanai, saglabāšanai un tālāknodošanai (Skujiņa 2007, 417). Citiem vārdiem sakot, valoda fiksē realitāti un tajā pastāvošos procesus un parādības, ietērpjot tās artikulētās skaņās vai rakstu zīmēs, tad secīgi virknējot vārdos un teikumos, kas pauž noteiktu nozīmi. Semantika ir viss valodas vienības izteiktais saturs jeb nozīme (Skujiņa 2007, 348), un semantiskie faktori, kas noteic sakārtotu komponentu secību, ir cieši saistīti ar to pausto saturu, kas ir tikpat daudzveidīgs, cik daudzveidīga ir pasaule, ko atspoguļo valoda. Tātad analizēt semantiskos faktorus, nedalot tos vairākās grupās atkarībā no komponentu nozīmes, būtu ne vien neproduktīvi, bet pat neiespējami.

Vairumā valodu teikuma komponentu lineārā secība tiek interpretēta kā realitātē norisinājušos notikumu secīgs atspoguḷojums (Siewierska 1988, 79), t. i., realitāte nosaka to, kā teikumā tiek secīgi sarindoti vārdi. Realitātes ietekme attiecināma uz vārdu secību ne tikai teikumā kopumā, bet arī vārdrindā, un realitātes noteiktais secīgums analizēts teju visos pētījumos par komponentu secību sakārtojuma konstrukcijā. Tas paredz, ka sakārtojumā saistīto komponentu secība atspoguḷo nosaukto procesu vai parādību īstenošanās kārtību ārpusvalodas realitātē (Lohmann 2013, 31).

Realitātes noteiktais secīgums pamato semantiski daudzveidīgu komponentu secību vārdrindā, taču ar to nevar skaidrot vārdu secību visos gadījumos. Hronoloǵiskās, cēloṇsakarīgās un loǵiskās attieksmes nav vien̄̄gās, kas pastāv starp parādībām un procesiem īstenībā. Cilvēks ir sabiedrības daļa, un sabiedrības radīta un to raksturojoša parādība ir hierarhiskas sistēmas. Hierarhiskā sistēmā iekḷautās vienības diferencē tām piešķirtais statuss. Tā ir sociāli kulturāla pazīme, ko piešķir cilvēks, nosakot kāda objekta vai procesa nozīmību un pārākumu vai pakḷautību hierarhiskā sistēmā. N̦emot vērā šādu sistēmu nozīmi sabiedrības struktūrā un cilvēka apziņā, hierarhiskās attieksmes, līdzīgi kā procesu vai parādību secīgums realitātē, tiek atspogulotas valodā, tostarp sakārtotu komponentu secībā (Zvīgule 2019, 47). Kā viens no semantiskajiem sakārtotu komponentu secību ietekmējošajiem faktoriem hierarhiskās attieksmes definējamas kā sabiedrībā pieņemto prioritāšu ierobežojumi, kas noteic, ka sakārtojumā saistīto komponentu secība atspoguḷo sabiedrības sociāli kulturālo un garīgo vērtību sistēmas (Malkiel 1959, 145).

Līdzās parādību un procesu savstarpējām attieksmēm būtiskas ir arī tās, kas veidojas starp parādību vai procesu un tā uztvērēju - indivīdu, valodas lietotāju. Valodā tiek formulētas domas un emocijas, tātad caur valodu tiek atklātas cilvēka pasaules uztveres, izziņas, psihologiskās un emocionālās īpatnības, kas ne tikai ir raksturīgas katram atsevišķajam indivīdam, bet kopīgas visiem cilvēkiem. Tas l̦auj definēt trešo semantisko - kognitīvi emocionālo - faktoru, kas apvieno ar indivīda emocionālo (egocentrisko) un racionālo (emocionāli neitrālo) pasaules uztveri saistītus principus (Zvīgule 2019, 28).

Tātad šķirami trīs semantiski aspekti, kas ietekmē un nosaka komponentu secību vārdrindā: 1) realitātes noteiktais secīgums, 2) hierarhiskās attieksmes, 3) kognitīvi emocionālie aspekti. 


\subsection{Realitātes noteiktais secīgums}

Realitātes noteiktais secīgums (angl. iconicity, iconic/scalar sequencing, arī universal sequencing conventions) kā viens no faktoriem, kas noteic komponentu secību vārdrindā, analizēts vairākos pētījumos (sk., piem., Cooper, Ross 1975; Allan 1987; Benor, Levy 2006; Lohmann 2013), turklāt tā ietekme uz komponentu secību vārdrindā konstatēta arī latviešu valodā. Tas dažkārt izvirzīts kā viens no ietekmīgākajiem semantiskajiem faktoriem, kas reti tiek pārkāpts (Lohmann 2013, 32). Turklāt arī gadījumos, kad postulēts viens visaptverošs princips, kas paredz noteiktu komponentu secību vārdrindā, realitātes noteiktais secīgums analizēts atsevišķi. Tā Viljams Kūpers un Roberts Džons Ross (William E. Cooper, Robert John Ross 1975, 65-67) izvirza vienu principu Es vispirms (angl. Me First), ko veido 19 semantiskās grupas, kuras katra koncentrēta ap vienu galveno jēdzienu, kas raksturo pirmo vārdrindas komponentu. Piem., semantiskajā grupā, kuras galvenais jēdziens ir vīrietis, iekḷautas vārdrindas vīrs un sieva, vīrietis un sieviete. Semantisko grupu galvenie jēdzieni raksturo prototipisko runātāju, kas ir te, tagad, pieaudzis, vīrietis, pozitīvs, patriotisks, draudzīgs, dzīvs utt. Tomēr V. Kūpers un Dž. Ross $(1975,102)$ atzīst, ka princips Es vispirms neizskaidro visas sakārtotu komponentu secības īpatnības, tostarp iespējamo semantisko universāliju - hronoloǵisko secību, kas paredz, ka, sakārtojumā saistoties diviem darbības vārdiem, pirmais apzīmē hronoloǵiski agrāk notikušu darbību. Līdzīgi arī Ģertrūde Fenka-Ocklona (Gertraud Fenk-Ozclon 1989, 529, 535) secinājusi, ka gadījumos, kad komponentu secība vārdrindā neatbilst postulētajam lietojuma biežuma principam, kas paredz, ka vārdrindas pirmais komponents vienmēr būs biežāk lietotais vārds, to iespējams pamatot ar realitātes noteiktu secīgumu, jo gan runātājam, gan klausītājam šāda secība valodā ir vieglāk uztverama.

Realitātes noteikta komponentu secība vārdrindā vērojama gadījumos, kad sakārtojumā saistītie komponenti nosauc parādības vai procesus, kas ekstralingvistiskajā pasaulē, respektīvi, realitātē, pastāv vai realizējas noteiktā secībā, turklāt to iespējams uzlūkot divējādi - vispārināti (1) un konsituatīvi (2) (Benor, Levy 2006, 240; Zvīgule 2019, 56):

(1) Saules sistēmas izveidošanās un evolūcija ir sākusies pirms 4,6 miljardiem gadu.

(2) Atspiežos pret baļ, gruēdu, иzрі̄poju.

Abos teikumos sakārtojumā saistīto komponentu secība ir pakḷauta realitātes noteiktam secīgumam, taču atšķirība ir tajā, ka saistīto komponentu semantika apvērstu secību piẹ̦auj tikai vārdrindā (2) teikumā, jo nosauktie procesi nav cēloṇsakarīgi saistīti. Tas nozīmē, ka realitātes noteiktais secīgums ir ne vien semantisks, bet arī pragmatisks aspekts, kas saistīts ar konkrētas situācijas atspogulojumu valodā. Konsituatīvās realitātes noteiktas komponentu secības izpratne saistāma ar Herberta Pola Graisa (Herbert Paul Grice 1995, 27) izvirzītajiem saziņas postulātiem, jo īpaši ar izteiksmes veida principu, kas noteic, ka izteikumam jābūt skaidram, nepārprotamam, īsam un secīgam. Attiecībā uz sakārtojuma konstrukcijām šis princips paredz, ka komponentu secībai jāataino aprakstīto notikumu hronoloǵiskā secība konkrētajā situācijā (Blakemore, Carston 2005, 570). Tātad ja vien saziņā tiek ievēroti P. Graisa saziņas postulāti, komponentu secību vārdrindā nosaka konsituatīvā realitāte vai - plašākā izpratnē - realitātes noteiktais secīgums. 
Realitātes noteiktais secīgums realizējas hronoloǵiskajā procesu vai parādību secībā, cēloṇa-seku attieksmēs un logiskajā secībā (Benor, Levy 2006, 239-240; Lohmann 2013, 31-32). Hronoloǵiskā un cēloṇa-seku noteiktā secība primāri saistāma ar realitāti kopumā un ārpusvalodiskām zināšanām, savukārt loǵiskais secīgums, lai arī balstīts notikumu un parādību secībā realitātē, saistāms ar sabiedrības veidotu, vispārpieņemtu lietu kārtību (Zvīgule 2019, 56). Hronoloǵiskā secība realitātē var būt vienīgais acīmredzamais semantiskais aspekts, kas noteic komponentu secību vārdrindā (piem., pagātne un tagadne), taču to var papildināt cēloņa-seku attieksmes, kas pastāv starp komponentiem, piem., jautājums un atbilde (Malkiel 1959, 146). Tā arī sakārtotu komponentu secība vienlaikus var būt saistīta gan ar hronoloǵisko, gan loǵisko secību, piem., pamatskola un vidusskola (Lohmann 2013, 32).

Par hronologiiski noteiktu uzskatāma komponentu secība šajos piemēros:

(3) Marija noslīgst uz soliņa pie vecās krāsns un raud.

(4) [..] komisija gan pagājušonedēl, gan šonedēl uzklausīja [..].

Minētajās vārdrindās komponenti nosauc laikā secīgi realizētus procesus (3) un laika vienības (4), sākot ar agrāko. Hronoloǵiski noteikta komponentu secība īpaši raksturīga dažāda veida instrukcijām - ēdiena pagatavošanas receptēm, tehniskām norādēm, lietošanas pamācībām u. c., piem., sīpolinus notīra, nomazgā un sagriež ripiņās vai pievienojiet austiņas, atblok,ējiet funkciju Hold un ieslēdziet atskan,otāju. Šajos gadījumos komponentu secību ietekmē nevis realitāte kopumā, bet konkrēta situācija, kur vēlamā rezultāta sasniegšanai nosauktās darbības veicamas noteiktā kārtībā.

Sakārtojumā saistīto komponentu secību nosaka arī cēloņa-seku attieksmes, kas pastāv starp to nosauktajām parādībām un procesiem:

(5) Tikšanās un šķiršanās, viss puķēs.

(6) [..] gājām gan turp, gan atpakal, [..].

(7) Mia atsperas pret laipu un rāmi ieslīd dīkīi.

Visos piemēros pirmais komponents vārdrindā nosauc vai raksturo agrāk notikušu darbību, kas uzskatāma arī par otrā komponenta nosauktās darbības cēloni. Tā (5) piemērā par šķiršanās cēloni uzskatāma tikšanās, savukārt (6) piemērā cēloņsakarība pastāv starp vietas apstākḷa vārdiem, jo nākt atpakal nav iespējams, nedodoties turp. (7) piemērā komponentu secību noteic cēloņa-seku attieksmes, kas izriet no konsituācijas, t.i., lai arī sakārtojumā saistīto darbības vārdu semantika nenorāda uz cēloṇsakarību starp nosauktajiem procesiem, apvērsts komponentu lietojums nav iespējams.

Nereti komponentu secību vienlaikus var noteikt gan notikumu hronoloǵiskā secība, gan cēloṇa-seku attieksmes, turklāt neveidojas pretruna, jo pēdējās pēc būtības ir hronologiska parādība:

(8) Vini raka, stādīja, novāca, pārdeva.

(9) Nokritu un sasitos.

Abos piemēros komponentu secība ir gan hronoloǵiski, gan cēloņsakarīgi noteikta, taču uz dominējošajām attieksmēm norāda komponentu semantika un iespēja secību apvērst. Tā (8) piemērā par primārām uzskatāmas cēloṇaseku attieksmes, jo nav pārdodams tas, kas nav novākts, un nav novācams tas, 
kas nav stādīts. Turpretim (9) piemērā primārās ir hronoloǵiskās attieksmes, jo cēloņsakarība ir konkrētās situācijas radīta - sakārtojumā saistīto darbības vārdu semantika noteikti neparedz tieši šādu procesu secību īstenībā un atkarībā no situācijas to iespējams apvērst.

Realitātes noteiktā logiskā secība ir saistīta ar sabiedrības radītu un vispārpieņemtu lietu kārtību, ko veido loǵiskas sistēmas, kurās ietilpstošās vienības ir secīgi sarindotas skalā vai sakārtotas daudzlīmeņu sistēmā (Benor, Levy 2006, 240). Loǵiskais secīgums paredz, ka komponenti tiks sarindoti atbilstoši to secībai loǵiskajā sistēmā, sākot no mazākās vienības uz lielāko:

(10) [..] dienām un nedêlāàm ilgi.

(11) [..] programmu sākumskolu, pamatskolu un vidusskolu pedagogiem.

(12) [..] no viņiem četri bērni - trīs, četrus, piecus un septiņus gadus veci [..].

(10) piemērā komponenti nosauc dažādas laika mērvienības, un tās sarindotas augošā secībā, (11) piemērā komponentu secību nosaka nosaukto parādību piederība loǵiskai daudzlīmeņu sistēmai un tā atbilst secībai no zemākā uz augstāko līmeni. Savukārt (12) piemērā nosauktas skaitliskas vērtības, kas sakārtotas saskaṇā ar loǵisko secīgumu realitātē - pirmajā pozīcijā nostājas komponents, kas nosauc mazāko vērtību.

Apkopotais valodas materiāls rāda, ka gadījumos, kad komponenti nosauc vienas sistēmas elementus (13) vai kāds no komponentiem nosauc daḷu, kas iekḷaujas otra nosauktajā veselumā (14), to secība var būt apvērsta:

(13) Saule, mēness un zvaigznes.

(14) [..] Baltijas jūras un Rīgas līča piekrastē [..].

(13) un (14) piemērā komponentu secība saistāma ar nosaukto vienību savstarpējām hierarhiskajām attieksmēm, kas noteic, ka komponents, kas nosauc sistēmas augstāka statusa vienību, nostāsies sakārtojuma konstrukcijas sākumā. Šādi gadījumi, kad saistīto komponentu semantika norāda uz nosaukto reāliju gan loǵisku, gan hierarhisku saistību, izskaidro, bet ne pilnībā pamato A. Lomaņa (2013, 34) piẹ̦āvumu, ka hierarhiskās attieksmes pastāv ārpus sociāli kulturālām un garīgām sistēmām un, sakārtojumā saistītajiem komponentiem nosaucot divas vienas skalas vērtības, pirmais komponents apzīmēs (skaitliski) lielāku vienību, piem., kilogrami un grami, dolāri un centi. Šis vispārinājums būtu jāuztver piesardzīgi, jo minētā komponentu secība sastopama specifiskos gadījumos, proti, kad nosaucami precīzi objekta izmēri ( 2 metri un 72 centimetri), daudzums (50 kilogrami un 253 grami) vai vērtība (23 478 eiro un 89 centi). Ja nosauktas tikai mērvienības, kuru daudzums nav minēts, latviešu valodā komponentu secība atbilst tai, ko noteic loǵiskais secīgums (centimetri, metri un kilometri, grami un kilogrami, centi un eiro, santìmi un lati).

Loǵiskas sistēmas noteikta komponentu secība ir gadījumos, kad tie sarindoti, balstoties nevis uz skaitliskiem rādītājiem, bet saskaņā ar latviešu valodas alfabētu:

(15) [..] Maltas, Rēzeknes un Viḷānu ugunsdzēsēji [..].

Par loǵiski noteiktu uzskatāma komponentu secība arī šādās vārdrindās:

(16) [..] augusta sākumā un augusta beigās.

(17) [..] ir ievads, 13 sadaḷas un noslēgums. 
(16) un (17) piemērā vārdrindas komponenti apzīmē procesa vai parādības stadijas vai daḷas, un ierastā secība ir šāda: sākums-vidus-beigas, sasaucoties ar to hronologíisko realizāciju realitātē.

Pamatojoties uz valodas datu ((1)-(17) piemērs) analīzi, secināms, ka valoda atspoguḷo realitāti un seko tās noteiktajai hronoloǵiskajai, cēloṇa-seku un loǵiskajai secībai gan vispārināti, gan noteiktā konsituācijā. Realitātes noteikta komponentu secība vienlaikus var būt saistīta ar vairākiem aspektiem un attieksmēm, kas pastāv starp komponentu nosauktajiem procesiem un parādībām. Īpaši tas attiecināms uz hronologisko un cēloņa-seku attieksmju mijiedarbi, jo pēdējās pēc būtības ir hronoloǵiska parādība. Tas nozīmē, ka gadījumos, kad komponentu secībā vērojama abu šo aspektu ietekme, būtiska ir ne tikai komponentu semantika, bet arī konsituācija. Ja komponentu semantika neuzrāda cēloņa-seku attieksmes starp to nosauktajiem procesiem vai parādībām, to secība ir konsituatīvi noteikta un var būt gan primāri hronoloǵiska un apvēršama (kā (9) piemērā), gan primāri cēloṇsakarīga un neapvēršama (kā (7) piemērā). Savukārt ārpus konteksta komponentu semantika ir vienīgais, kas nosaka, kādā - hronoloǵiskā, cēloņsakarīgā vai loǵiskā - secībā tie ir sarindoti.

\subsection{Hierarhiskās attieksmes}

Hierarhija ir 'secība no zemākā (amata, dienesta, sabiedriskā) stāvokḷa līdz augstākajam', arī 'secīga (jēdzienu, arī parādību) pakļautība (kādā sistēmā)'(„Latviešu literārās valodas vārdnīca”, turpmāk tekstā LLVV). Hierarhiskas sistēmas vienības diferencē tām piešķirtais statuss - sociāli kulturāla pazīme, ko piešķir sabiedrība, nosakot kāda objekta vai procesa nozīmību un pārākumu vai pakḷautību hierarhiskā sistēmā. Tātad hierarhiska sistēma ir sabiedrības radīta un arī to raksturojoša parādība, veids, kā tiek strukturēta realitāte. Līdzīgi kā hronoloǵiskais, cēloṇa-seku un loǵiskais secīgums realitātē, arī hierarhiskās attieksmes, kas pastāv starp sistēmas vienībām, tiek atspoguḷotas valodā, tostarp sakārtotu komponentu secībā (Malkiel 1959, 145; Zvīgule 2019, 47).

Hierarhiskās attieksmes kā vienu no semantiskajiem sakārtotu komponentu secību ietekmējošajiem aspektiem trāpīgi definējis J. Malkīls. Pētnieks tās raksturojis kā sabiedrībā pieņemto prioritāšu ierobežojumu, kas noteic, ka noteiktai sabiedrībai raksturīgo sociāli kulturālo un garīgo vērtību sistēmu atspoguḷo sakārtojumā saistītu komponentu secība un komponents, kas nosauc hierarhiski augstāk stāvošu, varenāku un augstāk vērtētu vienību, sakārtojuma konstrukcijā ieņems pirmo pozīciju (Malkiel 1959, 145). Vairums valodnieku sekojuši J. Malkīla izpratnei un hierarhiskās attieksmes šķīruši no citiem semantiskajiem faktoriem. Piem., Kīts Alans (Keith Allan 1987, 57-58) kā vienu no septiniem hierarhiskajiem principiem šķir personas, sociālā statusa un lomas hierarhiju (angl. personal, social status and role hierarchies), nodalot divas hierarhiskas sistēmas, kas nosaka to, kā tiks sarindoti komponenti sakārtojuma konstrukcijā. Pirmā un primārā ir personas hierarhija, kuras centrā atrodas cilvēks, „es”, savukārt otra ir sociālā hierarhija, kuras centrā atrodas par nozīmīgāku uztvertais elements. J. Malkīlam sekojuši arī S. Benora un R. Levi (2006, 239), izvirzot varas principu (angl. power constraint) un vispārināti to raksturojot kā ierobežojumu, kas saistīts ar zināšanām par pasauli, sabiedrību un tās organizāciju un paredz, ka komponents, kas nosauc nozīmīgāku elementu, vārdrindā būs pirmais. 
Arī latviešu valodā komponentu secība vārdrindā ir pakḷauta šim semantiskajam faktoram un pirmais komponents nosauc augstāk stāvošu un sabiedrības uztverē nozīmīgāku elementu. Sociāli kulturālu hierarhisko attieksmju noteikto secību visuzskatāmāk ilustrē dzimumu savstarpējās attieksmes gan sabiedrībā kopumā, gan ǵimenē. Dzimumu hierarhija noteic, ka sakārtojuma konstrukcijā pirmo vietu ieņems komponents, kas nosauc vīriešu dzimuma pārstāvi, kurš uztverts kā hierarhiskajā sistēmā augstāk stāvošs gan sociālā statusa, gan lomas ziṇā, piem.:

(18) [..] vīrieša un sievietes lomas evolūciju.

(19) Jorens nojauta, ka brāḷi un māsa tēva nāvē vaino vinuu.

Lai pārbaudītu, cik lielā mērā sakārtojumā saistīto komponentu nosauktās personas dzimums ietekmē to novietojumu vārdrindā, tika veikts lingvistisks eksperiments. Tam izmantots „Līdzsvarotais mūsdienu latviešu valodas tekstu korpuss", kur meklēti vārdu savienojumi vīrietis un sieviete//sieviete un vīrietis, brālis un māsa//māsa un brālis, vīrs un sieva//sieva un vīrs. Korpusā atrodama 541 sakārtojuma konstrukcija, no tām 359 vārdrindās ievērota hierarhisko attieksmju noteiktā secība un pirmais komponents nosauc vīriešu dzimuma pārstāvi, turpretim vārdrindas ar apvērstu komponentu secību sastopamas gandrīz divas reizes retāk - 182 teikumos.

Dzimumu hierarhiskās attieksmes noteic komponentu secību vārdrindā visos gadījumos, kad nosauktas dzīvas būtnes, ko iespējams pretstatīt pēc dzimuma, un paredz, ka dominējošā secība ir: vīrietis (vīriešu dzimuma pārstāvis) un sieviete (sieviešu dzimuma pārstāve), kas īstenojas semantiski daudzveidīgās vārdrindās, piem., kalpi un kalpones, suns, sunene un kaķis, gailis un vista. Šāda secība konstatēta visos analizētajos pētījumos, tomēr svarīgi apzināties, ka dzimumu hierarhiskās attieksmes ir sociāli kulturāla parādība un kultūrās, kur augstāks sociālais statuss ir sievietei, komponentu secība visdrīzāk būs pretēja (Malkiel 1959, 145; Benor, Levy 2006, 239).

Hierarhiskas attieksmes raksturo ne tikai dzimuma, bet arī vecuma kategoriju, kur par hierarhiski augstāk stāvošu atzìta vecāka, pieredzes bagātāka būtne. To parāda komponentu secība šādās sakārtojuma konstrukcijās:

(20) [..] mātes un bērna attiecībās.

(21) Patērzēe ar veciem un jauniem cilvēkiem, aprunājies ar augstskolu beidzējiem un pirmā kursa studentiem.

Ar dzimumu un vecumu saistīto hierarhisko attieksmju noteikta secība visbiežāk konstatējama konstrukcijās, kur saistīti divi lietvārdi. Atsevišķos gadījumos ar šo semantisko ierobežojumu pamatojama arī divu sakārtojumā saistītu īpašības vārdu secība. (21) piemērā īpašības vārdu secība pirms apzīmējamā vārda pakḷauta vecuma kategorijas hierarhiskajām attieksmēm, jo raksturota cilvēku grupa. Arī teikuma otrajā daḷā sakārtojumā saistītās vārdkopas augstskolu beidzēji (vecāki un pieredzējuši) un pirmā kursa studenti (jauni un nepieredzējuši) ir paḳ̣autas šim semantiskajam ierobežojumam.

Sociālās hierarhijas noteikto secību var pārkāpt vairāku iemeslu dēḷ. Pirmkārt, to ietekmē pieklājības normas (Malkiel 1959, 145; Allan 1987, 74), un, otrkārt, hierarhiskās attieksmes nav vienīgais semantiskais faktors, kas noteic komponentu secību vārdrindā, piem.: 
(22) Cienījamās dāmas un godātie kungi!

(23) Mamma un tētis [..].

(24) Paldies, mīlie vecāki un vecvecāki, ka katru dienu rūpējāties par mums [..].

(22) piemērā komponentu secību nosaka pieklājības normas un etiķete un vārdrinda ir valodā nostiprinājusies uzrunas formula, kas visbiežāk izmantota šādi. Savukārt (23) un (24) piemērā komponentu secību nosaka nevis dzimuma vai vecuma hierarhiskās attieksmes, bet kognitīvi emocionāli aspekti, kas paredz, ka komponents, kurš nosauc runātājam emocionāli tuvāku un nozīmīgāku personu (mamma un vecāki), tiks novietots konstrukcijas sākumā.

Dzimumu un vecumu savstarpējās hierarhiskās attieksmes sociālo sistēmu raksturo l̦oti šaurā skatījumā. Plašāk raugoties, par sociālām un kulturālām uzskatāmas visas sabiedrības pieņemtās un to organizējošās hierarhiskās sistēmas (ekonomiskās, politiskās, finanšu, reliǵiskās u.c. sistēmas) (sk., piem., Malkiel 1959, 145-146; Benor, Levy 2006, 239; Lohamnn 2013, 34). Hierarhiskās attieksmes, kas pastāv starp šo sistēmu dažādu līmeņu vienībām, atspogulojas arī valodā, piem., sabiedrības slān,ojums, šķiras:

(25) Latvijas sabiedrība arvien vairāk noslāņojas un sadalās bagātajos un trūcīgajos.

(26) Agrāk te dzīvoja kundzes un kalpones, kungi un ormaṇi.

(25) un (26) piemērā sakārtojuma konstrukcijā komponenti sarindoti saskaṇā ar sabiedrībā vispārpieņemtu priekšstatu par to, kas ir varenāks un augstāk stāvošs. Šo vienību apzīmējošais komponents nostājas pirms tāda, kas apzīmē statusa ziņā vājāku, zemāk stāvošu vienību. Šāda secība ievērota arī gadījumos, kad komponenti nosauc reālijas, kas saistītas ar valsts politisko sistēmu, piem., dažāda līmeņa un statusa iestādes (valsts un pašvaldība, gan Valsts kontrole, gan Ekonomikas ministrija), politiskās sistēmas dažāda ranga amatus (premjeri, ministri un deputāti, ierēdnis vai darbinieks) vai ietekmes ziṇā atšķirīgus likumdošanas normatīvus (Satversme un valsts likumi, Novērtējuma likums, kā arī Ministru kabineta noteikumi). Arī gadījumos, kad nosauktas citu hierarhisku (ekonomisku, finanšu un reliǵisku) sistēmu vienības, tās sarindotas atbilstoši statusam, sākot ar augstāk stāvošo, piem., īpašnieks vai turētājs, priekšsēdètājs vai sekretārs, dakteri, medicīnas māsas, kardināli, bīskapi, konsultanti.

Hierarhiskas sistēmas pastāv arī ārpus sociālās sfēras un ir saistāmas ar pasaules evolucionāro un mitoloǵisko redzējumu, kas daḷēji sasaucas ar K. Alana (1987, 57-59) postulēto personas un sociālā statusa un lomas hierarhiju. Evolucionārā pasaules redzējumā uz Zemes pastāvošās dzīvības formas ir bioloǵiskas sistēmas vienības, kur hierarhiski pārākā statusā atrodas cilvēks - augstākā dzīvības forma, turpretim jebkura cita dzīvības forma ir hierarhiski zemāka. Šāds pasaules uzbūves hierarhiskais modelis pamato komponentu secību turpmāk minētajos piemēros:

(27) Glābēji neatteiks palīdzību nelaimē nonākušajiem cilvēkiem, arī dz̄̄̄nniekiem.

(28) Miers pasaulē būs tad, kad nebūs vairs neviena suņa un nevienas nātres.

(29) [..] generālsekretārs nodrošina personālu un aprīkojumu, kas nepieciešams [..].

Skatot šos piemērus evolucionārā aspektā, secināms, ka hierarhiskās uzbūves augstā vispārinājuma pakāpē veidojas opozīcija dz̄̄vs organisms-neorganiska viela, 
ko iespējams izvērst šādi: cilvēks-dzīvnieki (fauna)-augi (flora)-nedzīvi objekti. Starp sistēmas elementiem pastāvošās hierarhiskās attieksmes nosaka semantiski daudzveidīgu komponentu secību, piem., Mihails un divi pērtiķ, mazu gliemežvāku un dzeltenīgu jūras zālu putra, balsis un traktora rūkon,a, par nozīmīgāku elementu atzīstot cilvēku attiecībā pret dzīvnieku vai nedzīvu objektu un dzīvnieku (ar faunu saistītu reāliju) attiecībā pret augu (Allan 1987, 57; Zvīgule 2019, 53).

Arī gadījumos, kad sakārtojumā saistītie komponenti nosauc vienas pakāpes vienības, to secība nav nejauša. Starp vienībām pastāv savstarpējas hierarhiskās attieksmes, kas veidojas saskaṇā ar konkrētā kultūrā pieņemtām vērtībām, piem.:

(30) Tāpēc ābeles, ceriņi un citi augi Baltijas jūras piekrastē uzzied [..].

(31) Toxoplasma gondii ir plaši sastopams mājlopos un savvaḷas dz̄̄vniekos.

Līdzās evolucionāram pasaules redzējumam pastāv mitoloǵisks pasaules uzbūves un sistēmas skatījums, kas hierarhijas virsotnē novieto par cilvēku augstākus, ne fiziskajai pasaulei piederīgus spēkus. Ar to iespējams skaidrot šādu sakārtojumā saistītu komponentu secību:

(32) Jēzus ir starpnieks starp Dievu un cilvēku [..].

(33) Jāṇu naktī ḷaunie gari, burvji un raganas esot sevišķi modri.

N̦emot vērā valodas datus, šo hierarhisko attieksmju ietekme vērtējama kā svārstīga, jo sastopamas arī sakārtojuma konstrukcijas, kur paredzamā secība nav ievērota - valdnieku un dievu statujas, laicīgi un reliǵiski l̦audis. Šādos gadījumos komponentu secība skaidrojama ar kognitīvi emocionālo principu un komponents, kas nosauc konkrētu fizisku parādību, vārdrindā nostāsies pirms abstraktas parādības nosaukuma.

Aplūkotie valodas piemēri uzskatāmi parāda, ka sakārtojumā saistītu komponentu secību ietekmē sociāli kulturāli aspekti, t.i., hierarhiskās attieksmes, valodā atspogulojot sabiedrības struktūru un tās vērtību sistēmas. Tomēr hierarhisko attieksmju noteiktā secība ir pārkāpjama gadījumos, ja saistîto komponentu semantika nenorāda uz nosauktās parādības viennozīmīgu piederību kādai sistēmai, kā arī tad, ja saistītajiem vārdiem konstatējamas papildnozīmes, kas par primārām izvirza nevis nosaukto parādību vai procesu savstarpējās attieksmes, bet gan tās, kas pastāv starp nosaukto procesu vai parādību un valodas lietotāju.

\subsection{Kognitīvi emocionālie aspekti}

Attieksmes, kas pastāv starp kādu procesu vai parādību un valodas lietotāju, raksturo cilvēka pasaules racionālā un emocionālā uztvere. Kognitīvie procesi un emocionālās īpatnības kā sakārtotu komponentu secību noteicoši faktori izvirzīti vairākos pētījumos. Daži tos aplūkojuši šķirti, piem., K. Alans $(1987,52,69)$ izvirzìjis tuvības (angl. familiarity hierarchy) un dominējošās iezīmes (angl. dominant descriptor hierarchies) principus, kas abi ir saistīti ar apkārtējās vides uztveri un tās parādību novērtējumu. Citi - S. Benora un R. Levi (2006), arī A. Lomanis (2013) pasaules uztveres dažādos aspektus skata vienkopus, izvirzot vienu semantisku faktoru, kas aptver daudzveidīgus principus.

S. Benoras un R. Levi pētījumā (2006, 237-238) izvirzìts divējāds - formāls (angl. formal markedness) un uztverē balstīts (angl. perception-based markedness) - marķējums, kas noteic, ka sakārtojuma konstrukcijā pirmo vietu 
ieņem mazāk marḳētā vienība, kura ir vieglāk uztverama un kognitīvi pieejama. Atšksirība ir tajā, kādā līmen̄i - valodas vai ekstralingvistiskajā - tiek noteikts marķētais un nemarḳētais opozīcijas loceklis un attiecīgi - tā pozīcija vārdrindā.

A. Lomanis $(2013,35)$ līdzās realitātes noteiktam secīgumam un hierarhiskajām attieksmēm šķir jēdzienisko pieejamību (angl. conceptual accesibility) - semantisku faktoru, kas ietver vairākus principus, kuri visi paredz vienu secību - vārdrindā pirmo vietu ienems komponents, kas nosauc vieglāk uztveramu un pieejamu (t. i., kognitīvi nemarķētu) jēdzienu. Šie principi postulēti kā antonīmu pāri un raksturo dažādas realitātes dimensijas, kā arī to uztveres un pieejamības pakāpi. Piem., pretstatot telpas dimensijas vertikāls-horizontāls, konstatēts, ka vārdrindā pirmo vietu ieņems komponents, kas saistīts ar cilvēkam vieglāk uztveramo vertikālo dimensiju, piem., augstums un platums, garš un tievs (Lohmann 2013, 35).

Analizējot vairākus pētījumus un to rosinātās atziṇas un secinājumus, izvirzāms viens semantisks - kognitīvi emocionālais - faktors. Tas apvieno principus, kas saistīti ar indivīda gan emocionālo (egocentrisko), gan racionālo (emocionāli neitrālo) pasaules uztveri. Daļa izvirzīto principu saistāmi ar fiziskās pasaules dimensijām un to uztveri, turpretim citi ir sociāli un kulturāli noteikti. Piem., princips pozitīvs-negatīvs paredz, ka sakārtojuma konstrukcijā pirmo vietu ieņems komponents, kas nosauc pozitīvi vērtētu procesu vai parādību, tomēr uzskati par to, kas ir pozitīvs vai negatīvs, dažādās sabiedrībās un kultūrās var atškirities (Benor, Levy 2006, 238).

N̦emot vērā, ka kognitīvi emocionālais aspekts attiecināms uz semantiski daudzveidīgu parādību loku, tā ietekme analizēta, šķirot vairākus principus pēc komponentu nosaukto parādību vai procesu pazīmēm (sk., piem., Allan 1987; Benor, Levy 2006; Lohmann 2013):

1) tuvs/nozīmīgs-attālināts/nenozīmīgs;

2) dzīvs-nedzīvs (stāvoklis/statisks-darbība/dinamisks);

3) konkrēts-abstrakts (objektīvs-subjektīvs, vispārināts-specifisks);

4) pozitīvs-negatīvs;

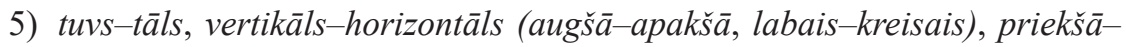
aizmugurēe, iekšs $\bar{a}-\bar{a} r \bar{a}$;

6) redze-dzirde-tauste-smarža-garša.

Lai arī lielākā daḷa principu izteikti kā opozīcijas, tie uztverami kā vienas skalas pretējas vērtības. Vienlaikus to izkārtojums norāda, kāda ir paredzamā komponentu secība sakārtojuma konstrukcijā, ja tie apzīmē vai ir ciešāk saistīti ar kādu no nosauktajām vērtībām.

Princips tuvs/nozīmīgs-attālināts/nenozīmīgs ir saistīts ar cilvēka emocionālo pasaules uztveri un paredz, ka komponents, kas nosauc runātājam vai adresātam emocionāli tuvāku, nozīmīgāku vai pat uztverē centrālu personu vai personas, vārdrindā ieņems pirmo vietu (Allan 1987, 52; Zvīgule 2019, 29):

(34) Paveiksim šo darbiņu, lai mammai un tētim būtu prieks!

(35) [..] lai pie kopēja galda sanāktu tuvinieki, draugi, kaimiṇi un nosvinētu [..].

Ja saistīti vairāk nekā divi šādi komponenti, tie tiek sarindoti atbilstoši to tuvības pakāpei, kā to uzskatāmi ilustrē (35) piemērs. Princips tuvs-attālināts noteic 
komponentu secību sakārtojuma konstrukcijās arī tad, ja kāds no komponentiem nosauc pašu runātāju vai personu grupu, kurai runātājs ir piederīgs:

(36) Bankas iekšpusē darbošos es un Imants.

(37) [..] starp mums un viņiem pastāv nepārvarama ideologiska plaisa.

(36) un (37) piemērā komponentu secība daḷeji sasaucas ar to, ko noteic pasaules evolucionārs redzējums, kur hierarhiskās sistēmas virsotnē atrodas cilvēks, taču atškirīība ir tajā, ka centrāls un nozīmīgs ir nevis cilvēks kā tāds, bet teksta autors.

Principa tuvs-attālināts noteikta sakārtoto komponentu secība ir arī šajos teikumos:

(38) [..] Pierunāja sieva un mamma.

(39) [..] vinam ir sieva un bērns!

Salīdzinot (34) un (38) piemēru, vērojamas interesantas izmaiņas vārdu secībā sakārtojuma konstrukcijā. Mainoties personas sociālajam statusam, mainās tās emocionālās izziṇas un uztveres lauks, kura centrā tiek izvirzîts laulātais draugs, nevis vecāki. (39) piemērā sakārtojumā saistīto komponentu secība atbilst divu semantisko faktoru - kognitīvi emocionālā principa tuvs-attālināts un hierarhisko attieksmju - noteiktai secībai.

Ar hierarhiskajām attieksmēm sasaucas arī kognitīvi emocionālais princips

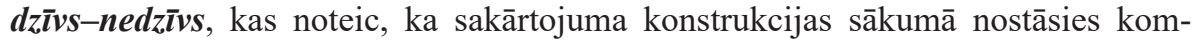
ponents, kas nosauc dzīvu būtni. No vienas puses, komponentu secību nosaka nosaukto parādību dažādie statusi evolucionārajā pasaules redzējumā. No otras cilvēks pasauli uztver un informāciju apstrādā egocentriski, īpašu uzmanību pievēršot būtiskām, pašam raksturīgām pazīmēm (Bock 1982, 15; Zvīgule 2019, 32). Dz̄ivums ir viena no tām, un, kā liecina psiholingvistiskie pētījumi, tā ir personas uztverei pieejamāka pazīme, tāpēc komponenti, kas apzīmē dzīvas būtnes, visbiežāk tiek novietoti teikuma sākumā (Bock 1982, 15). Šo atzinumu iespējams attiecināt arī uz sakārtojuma konstrukcijām latviešu valodā, jo komponents, kas nosauc dz̄ivu būtni, visbiežāk tiek novietots konstrukcijas sākumā:

(40) [..] vēroja cilvēkus un autobusus.

(41) Zemesmāte, tārpu, sakņu un klusuma māte.

(42) [..] trūkst cilvēkresursu, tehnologiskku iespēju un zināšanu.

(40) piemērā principa $d z \bar{\imath} v s-n e d z \bar{\imath} v s$ noteiktā komponentu secība ir visuzskatāmākā, turpretim pārējie piemēri ir specifiskāki. (41) piemērā pirmos komponentus vārdrindā - tārpi, saknes - grūti pielīdzināt cilvēkam, taču to būtiskā pazīme ir dzīvums, kas noteic šādu secību. Turklāt (41) piemērs uzskatāmi parāda, ka dzīvums kā pazīme var piemist lielākā vai mazākā mērā. (42) piemērā pirmais komponents nosauc dzīvu personu kopumu, tam seko komponents, kas apzīmē nedzìvu elementu kopumu (tehnologiskās iespējas), un visbeidzot arī abstraktu vienību (zināšanas). Šajā piemērā komponentu secība atbilst arī principa konkrētsabstrakts noteiktajai, ja analizēts pirmo divu komponentu pretstatījums pēdējam.

Principu $d z \bar{\imath} v s-n e d z \bar{\imath} v s$ iespējams raksturot no aktivitātes aspekta, šķirot papildu principu stāvoklis / statisks-darbība / dinamisks. Analizējot sakārtojumā saistītus darbības vārdus, S. Benora un R. Levi (2006, 240-241) izvirza atvērtas konstrukcijas (angl. setopen construction) principu, kas paredz, ka komponents, 
kurš nosauc stāvokli, ko iespējams saistīt ar vairākām relatīvi aktīvām darbībām, nostāsies vārdrindas sākumā. Šādas sakārtojuma konstrukcijas sastopamas arī latviešu valodā:

(43) a. Tà nav tāda vieta, kur tikai kāds sē̌̌ un lasa grāmatu.

b. Daniela sēèeja mašiñā un vēl arvien lürēja mobilajā.

(44) a. Garāžas durvīs stāvēja mazmeita, pavisam bāla, un teica, lai nenāk tuvumā.

b. Stāv, ausis atglaudis, un skatās, it kā jautādams: - Gribi vēl vai nu būs miers?

(45) a. Vienkārš̌i guḷ un skatās debesīs.

b. Viña gulēja gultā un skal̦i smējās.

Principa stāvoklis-darbība noteikta secība vērojama arī tad, ja nosaukts nevis fizisks, bet garīgs stāvoklis:

(46) Tèvs bija šokā un nerunāja ar mani visu vakaru.

(47) Viņš ir šoferis un brauc lieliski.

Atšķirībā no (43)-(45) piemēriem (46) un (47) teikumā vārdrindu komponenti ir semantiski ciešāk saistīti un pirmā komponenta semantika ierobežo otrā izvēli, taču to secība joprojām ir pakḷauta principam stāvoklis-darbība, jo otro komponentu ir iespējams mainīt. Komponentu secība šajās vārdrindās norāda arī uz nosauktā stāvokḷa vai aktīvas darbības pastāvību un ierobežojumu laikā, kas ḷauj pieņemt, ka vieglāk uztverams ir statisks objekta stāvoklis, savukārt laikā relatīvi ierobežota aktīva darbība ir grūtāk uztverama.

Sakārtojumā saistītu komponentu secību var noteikt kognitīvi emocionālais princips $\boldsymbol{k o n k r e ̄ t s - a b s t r a k t s . ~ T a s ~ p a r e d z , ~ k a ~ k o m p o n e n t s , ~ k a s ~ n o s a u c ~ f i z i s k a s , ~ a r ~}$ maņām uztveramas parādības vai procesus, vārdrindā nostāsies pirms tāda, kas nosauc abstraktas parādības vai procesus. Šāda secība saistīta ar indivīda pasaules uztveri, un, saskaņā ar pētījumiem kognitīvajā lingvistikā un psiholingvistikā, izziņai un uztverei pieejamākas un valodas apstrādes procesā vieglāk izgūstamas no apziņas ir konkrētas, fiziskas parādības un procesi, tāpēc tās teikumā (tostarp sakārtojuma konstrukcijā) ieņem sākuma pozīciju (Bock 1982, 17; Lohmann 2013, 37). To ilustrē piemēri:

(48) Gan apmeklējamie objekti, gan iespaidi bija dažādi.

(49) Ko vēl jūs redzējā̄t un piedz̄̄vojāt Griekijā?

Sakārtojumā saistītie lietvārdi (48) un darbības vārdi (49) nosauc dažādi uztveramas parādības un procesus, un pirmais komponents nosauc to, kas uztverams fiziski, turpretim otrais - abstraktu, ne fiziski uztveramu vai piedzīvojamu parādību vai procesu. Šì principa noteiktajai secībai pakḷauti arī īpašības vārdi (50) un apstākḷa vārdi (51):

(50) Viņš ir jauns, izskatīgs, gudrs vīrietis.

(51) Florence runāja maz un izvairīgi, visbiežāk cieta klusu.

Pirmie vārdrindā visbiežāk ir tādi īpašības vārdi un apstākḷa vārdi, kas nosauc raksturotās parādības vai procesa fizisku, ar maņām konstatējamu pazīmi. Otrais komponents nosauc abstraktu pazīmi, vienlaikus izsakot indivīda vērtējumu par aprakstītajām reālijām vai procesiem. 
Principa konkrēts-abstrakts noteikto secību iespējams pārkāpt, ja komponentu semantika norāda uz citām attieksmēm, kas pastāv starp to nosauktajām parādībām vai procesiem. Piem.:

(52) [..] vinuu mērķis un metodes ir lìdzīgi.

(53) Turpini negatīvi domāt un negatīvi runāt.

(52) un (53) piemērā vārdrindā saistīto komponentu secība ir pakḷauta realitātes noteiktajam secīgumam, precīzāk, cēloņa-seku attieksmēm. Šādos gadījumos principu konkrēts-abstrakts var neievērot, jo gan runātājam, gan klausītājam tā noteiktā secība būtu grūtāk uztverama, jo neatbilst notikumu realizācijai realitātē (Fenk-Ozclon 1989, 535).

Par principa konkrēts-abstrakts noteiktu secību iespējams runāt arī tad, ja visi saistītie komponenti nosauc tikai abstraktas vai konkrētas parādības, jo, kā minēts iepriekš, kognitīvi emocionālie principi uztverami ne tikai kā opozīcija, bet arī kāa skalāri pretmeti:

(54) [..] mūsu sirdis, mūsu dvēseles.

Šajā piemērā abi sakārtojumā saistītie komponenti nosauc abstraktas parādības, kas atšķiras pēc to abstrakcijas pakāpes. Vārds $d v \bar{s}$ sele nostājas vārdrindas otrajā pozīcijā, jo tā semantika ir ciešāk saistìta ar cilvēka garīgo pasauli, turpretim vārda sirds skaidrojumā tikai otrajā nozīmē minēts 'psihes, rakstura, personības emocionālo, morālo īpašību kopums'(LLVV).

Analoǵiski ir pamatojama komponentu secība arī gadījumos, kad tie nosauc konkrētas, fiziskas parādības, arī procesus vai to pazīmes - pirmais komponents nosauc konkrētāku reāliju:

(55) [..] tā daudzums un kvalitāte ir nepietiekama [..].

(56) [..] braucot gan ātri, gan pietiekami agresīvi [..].

(57) Bezgalīgs pelèku, netīru, smalku smilšsu klaids.

(55)-(57) piemērā visi vārdrindu komponenti nosauc konkrētu reāliju, procesu vai to pazīmi, tomēr pēdējā komponenta nosauktā parādība vai tās pazīme ir sarežǵītāk uztverama vai saistīta ar noteiktu vērtējumu. Tā vārdrindas komponenti (57) piemērā nosauc konkrētas pazīmes, ko diferencē to uztveramības sarežǵìitība. Pirmais komponents vārdrindā (pelēku) nosauc viegli konstatējamu un uztveramu objekta pazīmi, otrais komponents (netīru) nosauc pazīmi, kas konstatējama, pievēršot objektam pastiprinātu vērību, savukārt pēdējais komponents (smalku) tādu, kuras konstatēšanai raksturoto objektu nepieciešams pētīt vērīgi un ilgstoši. Tātad - jo lielākas pūles un laiks jāvelta kādas pazīmes noteikšanai, jo tālāk skalā konkrēts-abstrakts tā atvirzīsies no konkrētā.

Principu konkrēts-abstrakts, n,emot vērā, ka tas ir saistīts ar indivīda vērtējumu, var analizēt no objektivitātes/subjektivitātes viedokḷa, īpaši tad, ja sakārtojumā saistīti īpašības vārdi un apstākḷa vārdi. Šādā aspektā ar objektīvu raksturojumu saprotams tas, kas ir pārbaudāms un uztverams arī citiem cilvēkiem, turpretim subjektīvs raksturojums saistāms ar runātāja vērtējumu un var nesakrist ar citu vērtētāju izdarītajiem secinājumiem (Zvīgule 2019, 37). Piem.:

(58) [..] papīra driskas un vecas, nekur nederīgas lupatas.

(59) [..] piepeši skaḷi un pavēloši saka Malle. 
(58) un (59) piemērā īpašības vārdi un apstākḷa vārdi sakārtojumā sarindoti, ievērojot papildu principu objektīvs-subjektīvs. Abos piemēros pirmais komponents (vecas un skaļi) nosauc kopumā objektīvu, pārbaudāmu pazīmi, savukārt otrais komponents (nekur nederīgas un pavēloši) - subjektīvu vērtējumu. Komponentu secība, ko noteic runātāja (rakstītāja) objektīvs un subjektīvs vērtējums, sasaucas ar T. Porītes $(1954,56,62)$ novērojumiem par apzīmētāju secību pirms apzīmējamā vārda - īpašības vārds, kas precīzāk un būtiskāk raksturo apzīmējamo vārdu, nostājas tam tuvāk. Pazīmes būtiskums un precizitāte ir subjektīvs vērtējums, tāpēc sakārtojuma konstrukcijā ieņem pēdējo pozīciju.

Svarīgs jebkuras parādības raksturošanas priekšnosacījums ir spēja uztvert tās pazīmes. Latviešu valodā apzīmētāja funkcijā teikumā izmantojami gan īpašības vārdi, gan lokāmie divdabji. Pēdējie nosauc laikā ierobežotu, tāpēc grūtāk konstatējamu un objekta raksturošanas brīdī būtiskāku pazīmi. Tātad paredzams, ka tuvāk apzīmējamajam vārdam nostāsies lokāmais darāmās kārtas tagadnes vai pagātnes divdabis, kas nosauc attiecīgi priekšmeta stāvokli, kādā tas atrodas kādu laiku, vai sasniegtu stāvokli (Paegle 2003, 141, 142):

(60) [..] klausos viņu dziļajā, č̄̄kstošajā elpā.

(61) Caur kluso, pielijušo dārzu [..].

Šajos piemēros ar lokāmo darāmās kārtas divdabi nosauktās pazīmes ne tikai ir laikā pārejošas, bet objekta raksturošanas brīd̄i runātājs tās novērtējis kā būtiskākās un svarīgākās. Darbību vai stāvokli kā pazīmi, kas ir pastāvīga, būtiska, un pagātnē notikušu darbību kā stāvokli ar pasīvu nozīmi (Paegle 2003, 145, 146) izsaka ciešamās kārtas divdabji. To novietojums vārdrindā ir idents darāmās kārtas divdabju novietojumam:

(62) Magone ir jütīgs, trausls, netverams zieds [..].

(63) [..] lìdzi paņemt [..] kādu skaistu, pašu krāsotu olu Lieldienu atrakcijām.

No iepriekš minētā secināms, ka apzīmētāju (īpašības vārdu un lokāmo divdabju) secība vārdrindā saistāma ne vien ar runātāja subjektīvo vērtējumu, bet arī ar pazīmes pastāvību laikā un uztveramību. N̦emot vērā, ka ar divdabi izteiktas pazīmes konstatējamība ir atkarīga no tā, vai objekts tiek novērots laikā, kad šāda pazīme pastāv, tā uztverama kā drīzāk subjektīva parādības īpašība.

Gan konkrētas, gan abstraktas reālijas raksturojamas kā vispārinātas vai specifiskas, tāpēc princips konkrēts-abstrakts papildināms ar papildu principu vispārināts-specifisks. Tas sasaucas ar S. Benoras un R. Levi (2006, 236-237) izvirzịto formālā marḳējuma faktoru un reālijas / procesa centralitātes principu, kā arī A. Lomaņa $(2013,38)$ prototipiskuma principu. Princips vispārināts-specifisks noteic, ka sakārtojuma konstrukcijas pirmajā pozīcijā nostāsies tāds komponents, kurš nosauc semantiskas kategorijas prototipisko locekli vai kura nozīme ir vispārīgāka:

(64) Komisija veicina finanšu un kapitāla tirgus [..].

(65) [..] ikviens atlaujas smieties un ņirgāties, $k \bar{a}$ vien tīk.

(64) piemērā vārds finanses ('naudas līdzekḷu kopums' (LLVV)) ir vispārīgāks un ietver arī vārda kapitāls ('naudas līdzekḷi, kas atrodas apgrozībā' (LLVV)) nozīmi. (65) piemērā vārds ņirgāties norāda uz smiešanās veidu - l̦aunu izsmiešanu (LLVV). 
Ar parādību, procesu vai to pazīmju vērtējumu cieši saistīts kognitīvi emocionālais princips pozitīvs-negatīvs. Atšķirībā no principa konkrēts-abstrakts, ko raksturo subjektīvs, individuāls vērtējums, princips pozitīvs-negatīvs saistīts ar dažādu procesu vai parādību sociāli kulturālo vērtējumu (Benor, Levy 2006, 238). Saskaņā ar kognitīvās un psiholingvistikas atziṇām, pozitīvi vērtētu parādību vai procesu cilvēks uztver un apstrādā vieglāk un ātrāk nekā negatīvu (Bock 1982, 15-16; Lohmann 2013, 37). Tātad princips pozitīvs-negatīvs paredz, ka pirmais vārdrindā būs komponents, kas nosauc pozitīvi vērtējamu parādību, procesu vai to pazīmi:

(66) [..] var būt labvēlīgi, neitrāli vai naidìgi noskan,oti pret kustības darbību.

(67) [..] bijāt līdzās priekos un bēeās.

(66) un (67) piemērā saistīto komponentu semantika ietver pozitīvas vai negatīvas nozīmes elementus, kas noteic to secību, taču principa pozitīvs-negatīvs ietekme vērojama arī tad, ja komponentu semantikā šādu elementu nav:

(68) [..] un ieteikt optimālus risinājumus to novēršanai vai samazināšanai.

(69) Külas dedzināšanas dēl izdeg lauki, nodeg ēkas un cieš vai pat iet bojā cilvēki.

(70) [..] vai nu apzināti, vai neapzināti ir kļuvusi [..].

(71) [..] dosies dienas un nakts ekspedīcijās, kuru laikā k,ers un gredzenos putnus.

Šādos gadījumos komponentu secība ir saistīta ar sabiedrības uzskatiem un vērtējumu. Ne tikai sociāli kulturālā, bet arī reliǵiskā aspektā sabiedrībā pieņemtie uzskati piešksir konkrētai parādībai vai procesam vietu skalā no pozitīva uz negatīvu un noteic tā novietojumu vārdrindā. Šo principu, arī sabiedrības vērtējumu, raksturo dažādi pretmeti, piem., vēlams-nevēlams ((68) un (69) piemērs), esošsneesošs ((70) piemērs). (71) piemērā komponentu secību vārdrindā iespējams pamatot ar sabiedrībā pieņemto kulturāli reliǵisko pretmetu gaisma-tumsa, kur gaisma tradicionāli saistīta ar labo, pozitīvo. Tomēr šāda secība pamatojama arī ar realitātes noteikto secīgumu un to, ka cilvēka uztverē dienas jēdziens ir ne vien būtiskāks, bet arī pieejamāks, jo aktīvās dzīves un darba gaitas saistītas tieši ar dienu, nevis nakti (Benor, Levy 2006, 239).

Viena no plašākajām kognitīvi emocionālā faktora principu grupām ir saistīta ar telpas uztveri. Princips tuvs-tāls un ar to saistītie papildprincipi analizēti vairākos pētījumos un ir balstīti kognitīvās un psiholingvistikas atzin̄ās, ka cilvēka uztverei un izziṇai pieejamāki ir tādi jēdzieni, kas apzīmē tuvumā esošas reālijas un procesus (sk., piem., Benor, Levy 2006, 238; Lohmann 2013, 35, 39). Tuvs-tāls pēc būtības ir pielīdzināms principam tuvs-attālināts, taču attiecināms uz realitātes racionālo, emocionāli neitrālo uztveri. Piem.:

(72) Pēc ticējumiem Mārtiņš reizi gadā atjāj aplūkot sētas un laukus.

(73) Dažkārt der palūkot, ko dara tuvāki un tālāki kaimiņi.

(74) [..] kas dodas uz mājā̄m vai pasaulē.

Princips tuvs-tāls noteic, ka pirmais tiks minēts komponents, kas nosauc tuvāku vietu, turklāt telpa var būt gan reāla, gan abstrahēta. Tā (72) un (73) teikumā nosauktā telpa ir konkrēta, turpretim (74) piemērā nosauktās telpas uztveramas arī kā abstrakcija un komponentu secība pamatojama arī ar principu tuvs-attālināts, jo vārds mājas (74) piemērā neapzīmē 'celtni dzīvošanai', bet gan 'dzīvesvietu, dzimteni’ (LLVV), norādot uz emocionālu piesaisti. 
Princips tuvs-tāls vārdu secību sakārtojuma konstrukcijā var noteikt arī tad, ja saistītie komponenti nosauc dažādā laikā pastāvošas parādības vai procesus (Zvīgule 2019, 42):

(75) Asins nodošanu $R$. Daudze neuztver kā varoṇdarbu un nekad to tā nav uztvēris.

(76) [..] ar Latviju saista savu dzīvi šodien un nākotnē.

Šāda komponentu secība ir cieši saistīta ar spēcīgāku semantisko faktoru realitātes noteikto secīgumu. Atsevišksos gadījumos princips tuvs-tāls nosaka pretēju secību ((75) piemērs), taču visbiežāk tā noteiktā secība atbilst nosaukto parādību hronoloǵiskajai secībai realitātē ((76) piemērs). Tādēḷ princips tuvs-tāls attiecināms galvenokārt uz telpas dimensiju, savukārt attiecībā uz laika dimensiju daudz spēcīgāka ietekme ir tieši realitātes noteiktajam secīgumam un princips tuvstāls to vai nu papildina (gleznas tiks izsolītas rìt vai parīt), vai arī tiek pārkāpts (nedz toreiz, nedz tagad nav biedri) (Zvīgule 2019, 42).

Ar telpas uztveri saistāms princips vertikāls-horizontāls, un katru dimensiju attiecīgi raksturo papildu principi augš $\overline{\boldsymbol{a}}$-apakš $\overline{\boldsymbol{a}}$ un labais-kreisais. To ietekmi uz sakārtotu komponentu secību apstiprinājuši vairāki valodnieki, balstīdamies psiholoǵisko pētījumu atziņās, ka parādības, kas saistītas ar vertikālo asi, ir vieglāk uztveramas un apstrādājamas. Konstatēts arī, ka vertikālās un horizontālās ass uztverē pieejamāki ir jēdzieni, kas saistīti ar augšu un labo pusi (sk., piem., Cooper, Ross 1975, 88-91; Lohmann 2013, 35-36). Arī latviešu valodā komponentu secība vārdrindā ir pakḷauta principam vertikāls-horizontāls, piem.:

(77) [..] nepieciešams izmērīt karkasa augstumu un platumu.

(78) Mana dzīve ir kā Zvanu cel̦š - augšup un lejup, un sāṇus, uz vienu pusi un otru.

(77) un (78) teikumā vārdrindas pirmais komponents nosauc ar vertikālo asi, bet pēdējais - ar horizontālo asi saistītu reāliju vai tās pazīmi. Principa vertikālshorizontāls noteikta secība vienmēr sastopama tādās sakārtojuma konstrukcijās, kur saistītie komponenti nosauc dažādas debespuses vai ir saistīti ar ǵeogrāfisko koordinātu sistēmu (Cooper, Ross 1975, 84, 86), piem.:

(79) vējšs [..] no dienvidaustrumiem, austrumiem pakāpeniski iegriezīsies no ziemeḷiem, ziemel̦rietumiem.

(80) Varat meklēt konkrētu vietu pēc tās platuma un garuma GPS koordinātām.

Abi piemēri uzskatāmi rāda, ka attiecībā uz ǵeogrāfisko sistēmu (debespusēm un koordinātu sistēmu) komponenti, kas nosauc ar vertikālo asi saistītu elementu, ieņem pirmo vietu. Turklāt šāda secība ievērota arī salikteņos dienvidaustrumi un ziemel̦ietumi (79) piemērā. Savukārt (80) piemērā nosauktas ǵeogrāfiskās koordinātu sistēmas vienības un vārds platums, kas apzīmē attālumu no ekvatora ziemeḷu-dienvidu virzienā, tātad uz vertikālās ass, novietots sakārtojuma konstrukcijas sākumā.

Principu vertikāls-horizontāls raksturo papildu principi augšă-apakša un labais-kreisais, kas nosaka komponentu secību šādās vārdrindās:

(81) Zirgi vienmērīgi brida pa smilšu barhāniem augšup un lejup.

(82) [..] dāḷāju autogrāfus pa labi un pa kreisi un īgni grozījos krēslā. 
Šie principi tiek realizēti gandrīz vienmēr, kad saistītie komponenti atšķiras pēc to novietojuma uz vertikālās vai horizontālās ass, dodot priekšroku tam komponentam, kas apzīmē augstāk vai pa labi novietotu elementu. Turklāt princips augšā-apakšā realizējas semantiski daudzveidīgu komponentu saistījumā, piem., paliek krūšturī un biksītēs, pa kalniem un lejām, sadauzìts arī plecs un mugura.

Telpas uztvere noteic arī to, ka vārdrindā pirmie nostāsies komponenti, kas apzīmē priekšpusi un iekšpusi, tiem sekos tādi, kas apzīmē aizmuguri un ārpusi, piem., klanījās uz priekšu un atpakal, ne tikai iekšpolitisks, bet arī ārpolitisks lēmums. Šāda secība pamatojama ar to, ka parādības un procesi, kas atrodas cilvēka priekšā, ir vieglāk uztverami nekā tie, kas atrodas aiz muguras - tas skaidrojams ar ķermeņa fizioloǵisko uzbūvi (Benor, Levy 2006, 238). Savukārt princips iekšèjs$\bar{a}$ rējs un tā noteiktā komponentu secība pamatojama arī ar augstāku tuvinājuma pakāpi personai un tās uztveres laukam, turklāt cilvēka zināšanas par iekšējiem procesiem un parādībām nereti ir plašākas un dziḷākas, jo ir tiešāk saistītas ar pašu cilvēku un tam tuvāko apkārtni (Zvīgule 2019, 44).

Cilvēks fizisko pasauli uztver ar maņām - redzi, dzirdi, tausti, ožu un garšu -, kas atšķiras, pirmkārt, pēc nozīmības un, otrkārt, pēc to nodrošinātās informācijas pieejamības. Ar redzi, dzirdi un ožu dažādi kairinājumi uztverami no attāluma, savukārt garša un tauste prasa tiešu kontaktu ar objektu, tāpēc var uzskatīt, ka nozīmīgākas ir tās maņas, kas nodrošina ātrāku un vieglāku piekḷuvi informācijai. N̦emot to vērā, paredzams, ka vārdrindās, kur komponenti nosauc uztveres veidu, pirmais vārds nosauks jēdzienu, kas saistīts ar manu, kura nodrošina vieglāku informācijas uztveri (Zvīgule 2019, 44-45). To apstiprina arī latviešu valodas piemēri:

(83) [..] vielām, kas uzlabo produkta krāsu, smaržu [..].

(84) [..] bagātīgāku aromātu un garšu.

(85) Jo patiesi-mēs lielākoties redzam un dzirdam tikai to, ko gribam redzēt un dzirdèt.

Šāda secība ievērota arī tad, ja komponenti tieši nenosauc kādu no maṇām, bet gan pazīmi, kas ir saistīta ar noteiktā veidā uztvertu informāciju, piem., augstvērtīgu gaismu, video un skaņas priekšnesumu, taka iet plata un stingra. Savukārt, ja nosauktas vienā veidā uztveramas pazīmes, pirmā tiks minēta tā, kas konstatējama vieglāk un nav saistīta ar parādības vērtējumu:

(86) Izskatījās, ka nācējs uz muguras nes lielu, smagu nastu.

Šajā piemērā ar redzi runātājam ir uztveramas abas nosauktās pazīmes, tomēr to uztveres sarežgiîtība ir atšķirīga. Nastas izmēru runātājs nosaka vizuāli, turpretim tās svars runātājam nav ar maņām uztverams, par to liecina nācēja izskats. Tātad sakārtoto vārdu secība saistāma ar runātāja vērtējumu, jo pazīme smaga ir atkarīga no tā, kā runātājs uztver un apstrādā vizuālo informāciju (nācēja izskatu, izturēšanos, nesot nastu).

Vizuālo pasauli raksturo dažādi parametri - izmērs, forma, krāsa u. c. T. Porīte (1954, 52, 63) norāda, ka gadījumos, kad parādību vai priekšmetu raksturo vairākas pazīmes, komponents, kas nosauc parādības izmēru, apjomu, kā arī attīstības pakāpi laikā, visbiežāk nostājas tā komponenta priekšā, kas nosauc citu pazīmi, savukārt komponents, kas nosauc krāsu, nostājas tuvāk apzīmējamajam vārdam. To uzskatāmi apliecina arī šie piemēri: 
(87) Mitrais smidzeklis bija pārvērties sīkās, baltās sniegpārslās.

(88) Majestātiska savā garajā, krāšņajā pašas Atēnas austajā tērpāa [..].

(89) Salome uzsauca kundzìtei, kas sēdēja pie neliela, apaḷa galdiņa un lika pasjansu.

T. Porīte $(1954,64)$ šādu apzīmētāju secību izvirza kā latviešu valodā ierastāko, lai gan ne vienmēr ievērotu, jo iespējamas atkāpes, ja otrs apzīmētājs izteikts ar atvasinātu īpašības vārdu, kā arī tad, ja noteiktu pazīmi runātājs vēlas uzsvērt un tādēl novieto tuvāk apzīmējamajam vārdam. Kā galveno kritēriju, kas nosaka vārdu secību vārdrindā, autore izvirza apzīmētāju attieksmes pret apzīmējamo vārdu, kas noteic, ka tuvāk apzīmējamajam vārdam nostāsies tā pazīme, kas to raksturo sīkāk un precīzāk (Porīte 1954, 241). Šāds pamatojums nav noliedzams, tomēr to var papildināt, un sakārtojumā saistīto komponentu secību (88) un (89) piemērā pamatot ar nosaukto pazīmju uztveres secību, kas tiek atspoguḷota valodā. Ātrāk, vieglāk uztveramas pazīmes tiek minētas vispirms, savukārt tās, kuru uztvere saistīta ar noteiktu koncentrēšanos un piepūli, tiks minētas vēlāk (Bock 1982, 16; Zvīgule 2019, 46).

Līdzīga argumentācija saistāma ar dažāda izmēra objektu uztveramību, kas noteic, ka vieglāk uztverami, pamanāmi ir lielāki, nevis mazāki objekti. To atspogulı arī valoda:

(90) [..] tostarp kūkas, štriceles un smalkmaizītes.

(91) Bet mums šādu elektronu ir apmēram tik, cik zvaigžņu un planētu Visumā.

Šādās sakārtojuma konstrukcijās komponentu secību var noteikt objekta uztveramība, kas atkarīga no tā izmēra, tomēr jāṇem vērā, ka dažkārt starp nosauktajām parādībām var pastāvēt hierarhiskas attieksmes, kas paredz, ka komponents, kurš nosauc statusa ziņā augstāku vienību, nostāsies sakārtojuma konstrukcijas sākumā.

No analizētā valodas materiāla izriet, ka kognitīvi emocionālais faktors pamato semantiski ḷoti daudzveidīgu komponentu secību sakārtojuma konstrukcijās. Tas var būt gan vien̄̄gais faktors, kas nosaka komponentu secību konkrētā vārdrindā, gan arī viens no vairākiem semantiskajiem faktoriem, kas paredz vienādu secību. Dažkārt sakārtojuma konstrukcijās komponentu secība ir pretēja tam, ko nosaka kognitīvi emocionālie aspekti, visbiežāk gadījumos, kad komponentu nosauktās parādības vai procesi ir secīgi saistīti realitātē. Tādos gadījumos primārais faktors, kas nosaka komponentu secību, ir realitātes noteiktais secīgums. Secināms arī, ka kognitīvi emocionālā faktora noteiktā secība var sakrist (piem., attiecībā uz priekšmetu vizuālo uztveri) un var arī būt pretēja (attiecībā uz emocionālo pietuvinājumu izziņas laukam) tam, ko paredz hierarhiskās attieksmes, taču rūpīgi jāvērtē, vai komponentu nosauktās parādības vai procesi iekḷaujami vienā hierarhiskajā sistēmā.

\section{Secinājumi}

Latviešu valodā sakārtojumā saistītu komponentu secību ietekmē l,oti daudzveidīgi semantiskie aspekti. Kognitīvi emocionālie un sociāli kulturālie aspekti nosaka sakārtotu komponentu pamatsecību, t.i., tādu secību, kas nav atkarīga no konteksta un situācijas, kādā vārdrinda lietota. Tie ir saistīti ar cilvēka pasaules emocionālo un racionālo uztveri, kā arī ar zināšanām par dažādu sociāli 
kulturālu hierarhisko sistēmu uzbūvi, nevis konsituāciju. Turpretim realitātes noteiktajam secīgumam ir divējāda daba - tas ir gan semantisks, gan pragmatisks faktors, jo noteic sakārtotu komponentu secību ne tikai ārpus konteksta, bet arī noteiktā konsituācijā realitātē.

Vārdrindas komponentu secību var ietekmēt ne tikai viens, bet vienlaikus vairāki aspekti. Tiem savstarpēji mijiedarbojoties, vājākie tiek pārkāpti. Piem., realitātes noteiktais secīgums var noteikt kognitīvi emocionālajiem principiem pretēju secību (negatīvi domāt un negatīvi runāt), savukārt kognitīvi emocionālie faktori var būt spēcīgāki par hierarhiskajām attieksmēm (mamma un tētis).

Latviešu valodniecībā šis ir vēl pētāms jautājums - detalizētāk un daudz plašākā valodas materiālā būtu skatāma semantisko faktoru savstarpējā, arī iekšējā, mijiedarbe, t.i., kādi kognitīvi emocionālie, hierarhiskie vai realitātes noteiktie ierobežojumi ir izšķiroši, ja komponentu secība liecina par vairāku faktoru ietekmi. Plašāki pētījumi būtu nepieciešami arī par pārējiem, šajā rakstā neaplūkotajiem, funkcionāli pragmatiskajiem un formālajiem - faktoriem.

\section{Avoti}

1. Latviešu valodas sintaktiski mark̦ētais korpuss. Pieejams: http://www.korpuss.lv/ id/LVTB

2. Lìdzsvarotais mūsdienu latviešu valodas tekstu korpuss 2018. Pieejams: http://www.korpuss.lv/id/LVK2018

\section{Literatūra}

1. Allan, Keith. 1987. Hierarchies and the choice of left conjuncts (with particular attention to English). Journal of Linguistics. 23, 1, 51-77.

2. Bendiks, Hermanis et al. 1972-1996. Latviešu literārās valodas vārdnīca: 8 sējumos. Rīga: Zinātne. Pieejams: www.tezaurs.lv/llvv

3. Benor, Sarah B., Levy, Roger. 2006. The chicken or the egg? A probabilistic analysis of English binomials. Language. 82, 2, 233-278.

4. Blakemore, Diane, Carston, Robyn. 2005. The pragmatics of sentential coordination with and. Lingua. 115, 569-589.

5. Bock, Kathryn J. 1982. Towards a cognitive psychology of syntax: information processing contribution to sentence formulation. Psychological Review. 89, 1, $1-47$.

6. Cooper, William E., Ross, John R. 1975. World order. Papers from the parasession on functionalism. Grossman, Robin E., San, L. James., Vance, Timothy J. (eds.). Chicago: Chicago Linguistic Society, 63-111.

7. Fenk-Oczlon, Gertraud. 1989. Word frequency and word order in freezes. Linguistics. 27, 517-556.

8. Freimane, Inta. 1985. Vienkāršs teikums un tā paplašināšana. Rīga: Pētera Stučkas Latvijas Valsts Universitāte.

9. Grice, Paul. 1995. Studies in the way of words. Cambridge: Harvard University Press.

10. Lohmann, Arne. 2013. Constituent order in coordinate constructions a processing perspective. Dissertation Zur Erlangung der Würde des Doktors 
der Fachbereiche Sprache, Literatur, Medien \& Europäische Sprachen und Literaturen der Universität Hamburg. Hamburg: Universität Hamburg. Pieejams: http://ediss.sub.uni-hamburg.de/volltexte/2013/6409/pdf/Dissertation.pdf

11. Lokmane, Ilze. 2010. Vārdu secības funkcijas latviešu valodā. Latvistika un somugristika Latvijas Universitātē. Kalnača, Andra (red.). Rīga: Latvijas Universitāte, 59-68. Pieejams: https://www.hzf.lu.lv/fileadmin/user_upload/lu_ portal/projekti/hzf/petnieciba/7_Ilze_Lokmane_raksts.pdf

12. Lokmane, Ilze. 2013. Paralēli teikuma locekḷi sintaktisko sakaru aspektā. Valoda: nozìme un forma. 3. Teorija un metodologija latviešu valodniecībā. Kalnača, Andra, Lokmane, Ilze (red.). Rīga: LU Akadēmiskais apgāds, 87-97.

13. Malkiel, Yakov. 1959. Studies in irreversible binominals. Lingua. 8, 113-160.

14. Ozols, Arturs. 1993. Latviešu tautasdziesmu valoda. Rīga: Zvaigzne. [Pirmizdevums: Rīga: Latvijas Valsts izdevniecība, 1961.]

15. Paegle, Dzintra. 2003. Latviešu literārās valodas morfologịja. I. Rīga: Zinātne.

16. Porīte, Tamāra. 1954. Vārdu kārta mūsdienu latviešu literārās valodas vienkāršajā teikumā. Atributa un objekta vieta vienkāršajā teikumāa. Disertācija. Rīga: Latvijas PSR Zinātṇu akadēmijas Valodas un literatūras institūts.

17. Quirk, Randolph et al. 1985. A comprehensive grammar of the English language. London / New York: Longman.

18. Schachter, Paul. 1977. Constraints on coordination. Language. 53, 1, 86-103.

19. Siewierska, Anna. 1988. Word order rules. London / New York / Sydney: Croom Helm.

20. Skujiṇa, Valentīna (red.). 2007. Valodniecības pamatterminu skaidrojošā vārdnīca. Rīga: LU Latviešu valodas institūts.

21. Zvīgule, Guna. 2019. Sakārtojumā saistītu komponentu secība latviešu valodā. Maǵistra darbs. Rīga: Latvijas Universitāte.

\section{Summary}

The article deals with the order of coordinated components in Latvian. The analysed language material shows that the order of such components in Latvian is not grammatically determined, yet it is not arbitrary, either. As a result of theoretical and practical research, a number of factors that determine the order of coordinated components are proposed. These factors are: 1) semantic, 2) functional pragmatic, 3) formal factors.

This article is focused on semantic factors that determine the basic order of coordinated components in Latvian. As it is possible to coordinate words of an extremely varied meaning, the semantic factors are organised in groups according to the meaning of the conjoined words. The separate semantic aspects subject to analysis include: 1) iconic sequencing, 2) hierarchical relations, 3) cognitive-emotional perception.

The influence of these factors in Latvian is analysed in detail using the language data retrieved from "Latvian Treebank" and "The Balanced Corpus of Modern Latvian". While several constraints were set, the retrieved language material used for practical research is semantically extensive and varied, as it includes coordinate structures of nouns, verbs, adjectives and adverbs.

Keywords: coordination; word order; coordinative word group; semantics; semantic factors. 